\title{
Melaspilea galligena sp. nov. and some other lichenicolous fungi from Russia
}

\author{
Mikhail P. Zhurbenko ${ }^{1} \&$ Ilya S. Zhdanov ${ }^{2}$ \\ ${ }^{1}$ Laboratory of the Systematics and Geography of Fungi, Komarov Botanical Institute, \\ Russian Academy of Sciences, Professora Popova str., 2, St. Petersburg, 197376, Russia. \\ E-mail: zhurb58@gmail.com \\ ${ }^{2}$ Laboratory for Synecology, A. N. Severtsov Institute of Ecology and Evolution, \\ Russian Academy of Sciences, Leninskii Prospect, 33, Moscow, 119071, Russia. \\ E-mail: iszhdanov@yandex.ru
}

\begin{abstract}
Thirty species of lichenicolous fungi are reported, many being new to various regions of Russia. Melaspilea galligena sp. nov. growing on Pertusaria cf. cribellata is described from Russian Far East. A possibly new lichenicolous Toninia species (on Parmelina tiliacea) and a species of Arthonia (on Cladonia) with 1-2-septate ascospores resembling poorly known $A$. lepidophila are described, illustrated and discussed. Dactylospora suburceolata is reported new to Russia and Asia, growing on a new host species Mycobilimbia carneoalbida. Tremella cetrariicola is new to Siberia and Clypeococcum cetrariae is newly documented on Vulpicida.
\end{abstract}

\section{INTRODUCTION}

Taxonomic diversity and distribution of lichenicolous fungi of Russia is still far from being reasonably revealed. This is proved by results of identification by the first author of miscellaneous specimens of these fungi collected by the second author in various regions of Russia presented below. The aims of the paper are to describe a new lichenicolous Melaspilea species and draw attention to another possibly new lichenicolous Toninia species, as well as discuss some insufficiently known species and provide new information on distribution and ecology of lichen-dwelling fungi.

\section{MATERIAL AND METHODS}

The specimens were examined using Zeiss microscopes Stemi 2000-CS and Axio Imager A1 equipped with Nomarski differential interference contrast (DIC, $\times 1000)$ optics. Microscopical examination was done in water, $10 \% \mathrm{KOH}(\mathrm{K})$, Lugol's iodine directly (I) or after a $\mathrm{KOH}$ pretreatment (K/I), Brilliant Cresyl blue (BCr), 10\% $\mathrm{HNO}_{3}(\mathrm{~N})$ or etanol solution of paraphenylenediamine $(\mathrm{P})$. The length, breadth and length/ breadth ratio $(1 / \mathrm{b})$ of ascospores are given as: $(\min -)\{\overline{\mathrm{X}}-\mathrm{SD}\}-\{\overline{\mathrm{X}}+\mathrm{SD}\}(-\max )$, where min and $\max$ are the extreme values, $\bar{X}$ the arithmetic mean, and SD the corresponding standard deviation.
All specimens have been collected by Ilya S. Zhdanov and identified by Mikhail P. Zhurbenko. Biogeographic novelties are mainly referred to the current administrative subdivision of Russia. Examined specimens are deposited in LEFungi herbarium.

\section{THE SPECIES}

ARTHONIA sp. - Krasnoyarsk Territory, Evenkiya District, lower Podkamennaya Tunguska River, Central Siberian Biosphere Reserve, near Stolbovaya River mouth, 62 ${ }^{\circ} 07^{\prime} 23.1^{\prime \prime} \mathrm{N}$, 91 $1^{\circ} 30^{\prime} 54.8^{\prime \prime E}$, Pinus sylvestris-Larix forest, on basal squamules of Cladonia sp. growing on bark of Pinus sylvestris, 14.08.2008 (LE 260900).

Description - Vegetative hyphae immersed, brown, flexuose, 2-4 $\mu \mathrm{m}$ diam. Ascomata brownish black, glossy, rough, superficial, irregularly convex to subglobose, $50-180 \mu \mathrm{m}$ diam., dispersed, contiguous or fused (then up to $500 \mu \mathrm{m}$ across) (Fig. 1); section $\mathrm{K}$ - in all parts. Epithecium medium olive brown, ca. $5 \mu \mathrm{m}$ tall. Hymenium pale olive brown above, hyaline below, 25-35 $\mu \mathrm{m}$ tall, I+ red, K/I+ blue with red stripes. Paraphyses rather indistinct. Hypothecium pale olive brown to almost hyaline, 20-30 $\mu \mathrm{m}$ tall. Asci broadly clavate, 24-28(-31) 


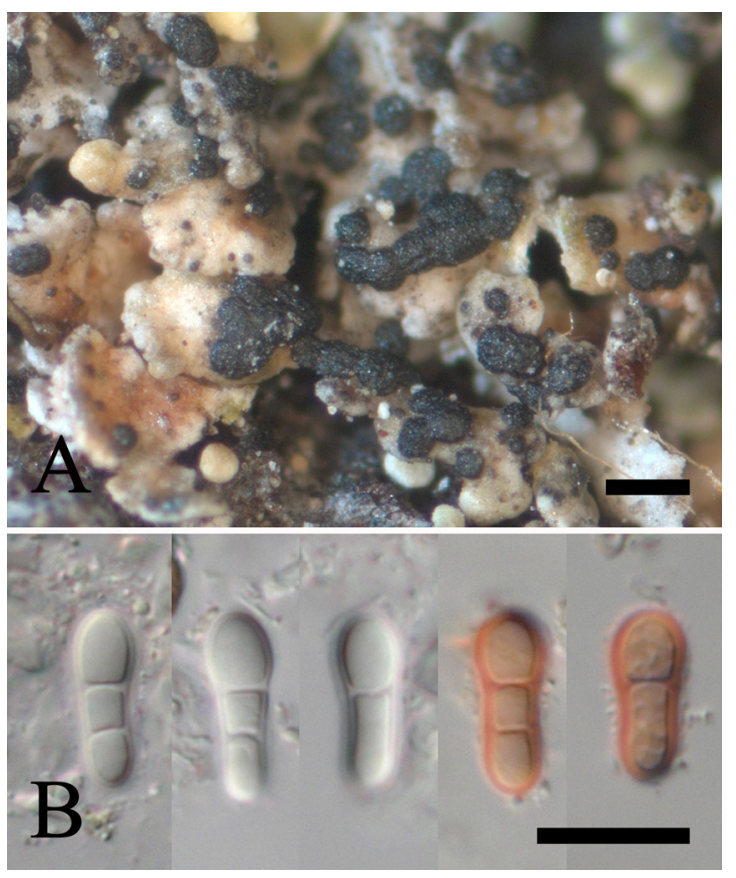

Fig. 1. Arthonia sp. (LE 260900). A - habitus of apothecia; B - ascospores (left, in water; right, in I). Bars: $A=200 \mu \mathrm{m} ; \mathrm{B}=10 \mu \mathrm{m}$.

$\times(11-) 12-16(-17) \mu \mathrm{m}(\mathrm{n}=12$, in water or $\mathrm{I})$, 8-spored. Ascospores hyaline, soleiform, with enlarged to often capitate upper cell, (9.0) 10.7-13.1(-14.4) × (3.5-)3.9-4.7(-5.3) $\mu \mathrm{m}, 1 / \mathrm{b}$ $=(2.2-) 2.5-3.1(-3.5)(\mathrm{n}=55$, in water, $\mathrm{I}, \mathrm{K}$ or $\mathrm{K} / \mathrm{I}), 1-2$-septate, wall ca. $0.5 \mu \mathrm{m}$ thick, smooth, distinct halo not observed (Fig. 1). Grows on the upper side of Cladonia basal squamules and on its podetium, which are distinctly bleached under infection.

Notes - The only formerly known Arthonia species growing on Cladonia and having ascospores with more than one septum is A. lepidophila (Anzi) Clauzade, Diederich \& Cl. Roux ined. Description of this species, yet known only from old collections in the Alps (Anzi, 1868; Keissler, 1930), fits in general examined material, but differs in stating ascomata with greenish pruina, longer asci $(60 \times 10-12 \mu \mathrm{m})$, and $1-3$-septate ascospores.

Clypeococcum CETRARIAe Hafellner - Krasnoyarsk Territory, Evenkiya District, lower Podkamennaya Tunguska River, Central Siberian Biosphere Reserve, near Stolbovaya River mouth,
6207'56.3"N, 9132'11.2"E, Pinus sylvestrisPicea obovata forest, on the upper side of Vulpicida pinastri lobes, 18.07.2009 (LE 260729).

Notes - Ascomata 50-90 $\mu \mathrm{m}$ diam. Asci with 4 mature, but sometimes with 5-6 germinating spores. Ascospores medium olive brown to dark brown, verruculose (clearly seen in moderately pigmented spores), halo not observed, $(12.2-) 13.4-15.0(-16.2) \times(5.5-) 5.8-7.0(-8.5)$ $\mu \mathrm{m}, 1 / \mathrm{b}=(1.6-) 2.0-2.4(-2.6)(\mathrm{n}=64$, in water). In the species protologue (Hafellner, 1994) its ascomata were described being ca. 80-120 $\mu \mathrm{m}$ diam. and ascospores somewhat narrower (13$17 \times 4.5-6 \mu \mathrm{m})$ and with thin halo when young. The species was formerly known in Russia from a single finding in arctic Yakutiya (Zhurbenko, 2002a). Previously reported only from Cetraria and Flavocetraria species, Vulpicida being a new host genus.

Corticifraga fuckeli (Rehm) D. Hawksw. \& R. Sant. - Murmansk Region, Lapponia Imandrae, Kandalaksha Nature Reserve, Por'ya Bay, Glubokie Ludy Islands, Glubokii Island, $66^{\circ} 43^{\prime} 20.8^{\prime \prime} \mathrm{N}, 33^{\circ} 48^{\prime} 58.4^{\prime \prime} \mathrm{E}$, Populus tremula forest, on thallus of Peltigera rufescens, 27.06.2010 (LE 260649).

Note - Known from many regions of Russia, including Murmansk Region (Zhurbenko, 2001, 2007).

DACTYLOSPORA AMYGDALARIAE Triebel - Murmansk Region, Lapponia Imandrae, Iolgi-Tundry Mountains, S bank of Maloe Glubokoe Lake, $67^{\circ} 12^{\prime} 40^{\prime \prime} \mathrm{N}, 33^{\circ} 14^{\prime} 40^{\prime \prime} \mathrm{E}$, rocks in Picea obovataBetula forest, on cephalodia of Amygdalaria elegantior, 23.07.2001 (LE 260738).

Note - Known from many regions of Russia, including Murmansk Region (Zhurbenko, 2007, 2009).

Dactylospora deminuta (Th. Fr.) Triebel - YamalNenets Autonomous Area, E coast of Baidaratskaya Bay, near Yarayakha River mouth, $69^{\circ} 16^{\prime} 13.2^{\prime \prime} \mathrm{N}, 68^{\circ} 07^{\prime} 28.3^{\prime \prime} \mathrm{E}$, wooden house in tundra, on apothecia and thallus of Biatora subduplex growing on lignum, 6.08.2007 (LE 260648).

Note - Known from many regions of Russia, including Yamal-Nenets Autonomous Area (Zhurbenko, 2007, 2009).

DACTYLOSPORA SUbURCEOLATA Coppins \& Fryday - Krasnoyarsk Territory, Turukhansk District, 
near Podkamennaya Tunguska River mouth, Central Siberian Biosphere Reserve, right bank of Enisei River in front of N extremity of Komsinskii Island, $61^{\circ} 53^{\prime} \mathrm{N}, 89^{\circ} 20^{\prime} \mathrm{E}$, Abies sibiricaPicea obovata forest, on thallus of Mycobilimbia carneoalbida growing on bark, 7.07.2009 (LE 260880).

Notes - Ascospores (15.3-)16.2-21.0(-25.8) × (5.0-)5.6-7.4(-8.9) $\mu \mathrm{m}, 1 / \mathrm{b}=(2.1-) 2.5-3.3(-3.9)$ $(\mathrm{n}=66$, in $\mathrm{K}),(1-) 3-$ septate, not to markedly constricted at the septa, granulate (seen only in DIC optics!), often guttulate. This recently described species (Fryday \& Coppins, 2012) is remarkable for its granulate ascospores (Fig. 2), rarely occurring in the genus. It was so far known from Scotland and Switzerland (Fryday $\&$ Coppins, 2012). New to Russia and Asia. My cobilimbia carneoalbida is a new host species.

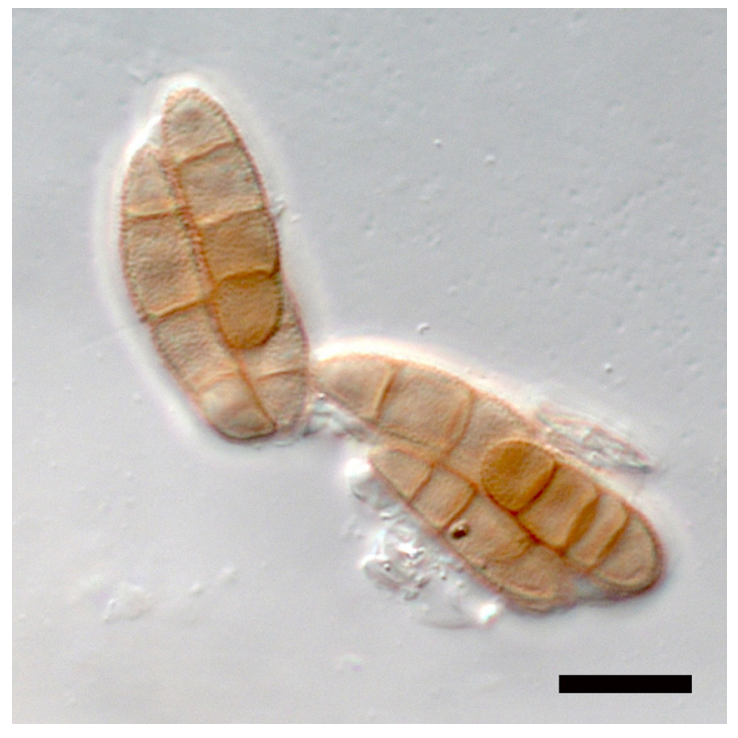

Fig. 2. Dactylospora suburceolata (LE 260880). Granulate ascospores (in K, 100× oil immersion objective, DIC optics).

Endococcus Rugulosus Nyl. s. 1. - Murmansk Region, Lapponia Imandrae, Kolvitskie Tundry Mountains, top of Domashnyaya Mountain, $67^{\circ} 03^{\prime} 30^{\prime \prime} \mathrm{N}, 32^{\circ} 58^{\prime} 00^{\prime \prime} \mathrm{E}$, alt. $460 \mathrm{~m}$, rocks in mountain tundra, on thallus of Rhizocarpon copelandii, 4.09.2001 (LE 260779). - YamalNenets Autonomous Area, SW coast of Baidaratskaya Bay, lower Ngoyuyakha River mouth, $68^{\circ} 45^{\prime} 57.8^{\prime \prime} \mathrm{N}, 66^{\circ} 43^{\prime} 17.7^{\prime \prime} \mathrm{E}$, rocks by the river bank, on thallus of Aspicilia sp., 28.07.2007 (LE 260728).

Note - Known from many regions of Russia, including Murmansk Region and Yamal-Nenets Autonomous Area (Zhurbenko, 2007, 2009; Urbanavichus et al., 2008).

Geltingia Associata (Th. Fr.) Alstrup \& D. Hawksw. - Yamal-Nenets Autonomous Area, SW coast of Baidaratskaya Bay, E of Ngoyuyakha River mouth, $68^{\circ} 51^{\prime} 01.1^{\prime \prime} \mathrm{N}, 66^{\circ} 53^{\prime} 03.0^{\prime \prime} \mathrm{E}$, tundra, on thallus of Ochrolechia sp. growing on mosses, 30.07.2007 (LE 260698a); E coast of Baidaratskaya Bay, near Yarayakha River mouth, $69^{\circ} 16^{\prime} 27.9^{\prime \prime} \mathrm{N}, 68^{\circ} 08^{\prime} 58.9^{\prime \prime} \mathrm{E}$, tundra, on apothecia and thallus of Ochrolechia inaequatula, 6.08.2007 (LE 260688).

Note - New to Western Siberia.

Homostegia PigGoti (Berk. \& Broome) P. Karst. - Murmansk Region, Karelia Keretina, Kandalaksha Nature Reserve, S coast of Velikii Island, $\mathrm{NE}$ of Cape Kindo, near Lobanikha Bay, $66^{\circ} 33^{\prime} 16.1^{\prime \prime} \mathrm{N}, 33^{\circ} 15^{\prime} 08.6^{\prime \prime} \mathrm{E}$, rocks in Pinus sylvestris forest, on thallus of Parmelia saxatilis, 26.08.2007 (LE 260629).

Note - New to Murmansk Region.

InTRALICHEN LICHENICOLA (M.S. Christ. \& D. Hawksw.) D. Hawksw. \& M.S. Cole - Central Federal District, Ryazan Region, Spassk District, Okskii Biosphere Reserve, near Lipovaya Gora Cabin, $54^{\circ} 44^{\prime} 00.1^{\prime \prime} \mathrm{N}, 40^{\circ} 58^{\prime} 10.3^{\prime \prime} \mathrm{E}$, on hymenium of apothecia of Candelariella aurella growing on concrete pillar, 25.07.2010 (LE 260610).

Note - The species was formerly known in Central Federal District only from Tver Region (Notov et al., 2011).

LiCHENOCHORA POLYCOCCOIDES Hafellner \& R. Sant. - Murmansk Region, Lapponia Imandrae, Kandalaksha Nature Reserve, near Luven'ga, S coast of Vlasov Berezhnoi Island, $67^{\circ} 04^{\prime} 30^{\prime \prime} \mathrm{N}$, $32^{\circ} 42^{\prime} 00^{\prime \prime} \mathrm{E}$, on thallus of Physcia dubia growing on coastal rocks, 8.07.2005 (LE 260609).

Note - New to Murmansk Region.

Lichenoconium pyxidatae (Oudem.) Petr. \& Syd. - Krasnoyarsk Territory, Evenkiya District, lower Podkamennaya Tunguska River, Central Siberian Biosphere Reserve, lower Tanimakit River, 62 $2^{\circ} 30^{\prime} 00.4^{\prime \prime} \mathrm{N}, 91^{\circ} 29^{\prime} 50.8^{\prime \prime} \mathrm{E}$, on moribund podetia of Cladonia coniocraea growing on rotten wood, 18.08.2008 (LE 260860). 
Note - The species was formerly known in Krasnoyarsk Territory (Central Siberia) only from Severnaya Zemlya Archipelago (Zhurbenko \& Alstrup, 2004).

\section{Melaspilea Galligena Zhurb. \& I. Zhdanov sp. nov.}

MycoBank No. - MB 804578

Similar to Labrocarpon canariense, but without periphysoids, with larger ascospores, (20.7-) 22.5-25.9(-30.0) × (10.0-)11.2-13.6(-15.6) $\mu \mathrm{m}$ vs. $(13.8-) 15.4-19.8(-21.0) \times(6.0-) 6.8-8.6(-9.5)$ $\mu \mathrm{m}$, and inducing galls-formation.

Type - Russia, Primorye Territory, Chuguevka District, Sikhote-Alin' Range, Snezhnaya Mountain, $43^{\circ} 44^{\prime} 15.2^{\prime \prime} \mathrm{N}, 134^{\circ} 25^{\prime} 35.5^{\prime \prime} \mathrm{E}$, alt. 1510 $\mathrm{m}$, stone field among Pinus pumila shrubs, on saxicolous Pertusaria cf. cribellata (thallus), 17.09.2007, I. S. Zhdanov (LE 260769 - holotype).

Description (Fig. 3) - Ascomata originating deeply in the host thallus, initially completely immersed, closed, round to ellipsoid in cross section, then erumpent (but still immersed, never superficial) and widely exposing the hymenium, more or less cup- or saucer-shaped in cross section, often with bent inward margins, irregularly angular rounded to elongated in surface view, up to $650 \mu \mathrm{m}$ across; disk black, matt, rough, at first dot- or slit-like, then exposed, at the host thallus level, more or less flat, surrounded by concolorous, elevated, tuberous excipular margin; dispersed, contiguous or fused by a few and sometimes looking multilocular, aggregated by up to 150 or more on bullate galls up to $6.5 \mathrm{~mm}$ across concolorous with the host thallus. Proper exciple cupulate when mature, continuous below the hymenium, often flat at the base, dark brown, uneven in thickness, in cross section of textura intricata; $\mathrm{K}+$ olive brown; lateral part 30-100 $\mu \mathrm{m}$ thick, usually markedly swollen and with protruding rounded hyphal tips in the uppermost part; basal part mainly $15-40 \mu \mathrm{m}$ thick, occasionally with up to $80 \mu \mathrm{m}$ thickened portions usually located in its center. Epithecium medium brown, finely granulose, 20$30 \mu \mathrm{m}$ tall, $\mathrm{K}+$ olive brown. Hymenium hyaline, occasionally with reddish crystalline speckles (DIC optics!), 70-120 $\mu \mathrm{m}$ tall, I-, K/I+ pale blue. Hypothecium indistinct, hyaline to pale brown, 10-20 $\mu \mathrm{m}$ tall. Hamathecium completely filling ascomata initials and at that stage resembling interascal pseudoparenchyma, later of fre- quently branched, anastomosed, septate, often constricted at the septa paraphyses composed of very unequal, often angular inflated cells $2-9 \mu \mathrm{m}$ diam., with swollen, conglutinated tips 4-9.5 $\mu \mathrm{m}$ diam. Asci elongate-clavate, generally with tall tholus and distinct ocular chamber, ca. 70-90 $\times$ $20 \mu \mathrm{m}$, plasma I and $\mathrm{K} / \mathrm{I}+$ pale yellow to orange, otherwise I and K/I-, (6-)8-spored. Ascospores long pale then medium brown, sole-shaped to broadly obovate, 1-septate, usually markedly constricted at the septum, with upper cell broader than lower one, rounded at the ends, (20.7)22.5-25.9(-30.0) × (10.0-)11.2-13.6(-15.6) $\mu \mathrm{m}$, $1 / \mathrm{b}=(1.6-) 1.8-2.2(-2.5)(\mathrm{n}=116$, in water, $\mathrm{I}, \mathrm{K}$ or $\mathrm{K} / \mathrm{I})$, sometimes with $1(-2)$ large guttules in each cell (better seen in K), wall smooth, thin, readily tearing in squash preparations, without halo, $\mathrm{K}+$ grey or vinaceous brown. A conidioma with hyaline, bacilliform, rounded at the apex and truncate at the base conidia ca. $7-8 \times 1.5$ $\mu \mathrm{m}$ was found among ascomata of the fungus. The species grows on thallus of saxicolous Pertusaria cf. cribellata (mature ascospores not found, section of verrucae $\mathrm{K}+$ red, $\mathrm{P}+$ orange). The fungus induces galls, otherwise symptoms of distinct pathogenicity were not observed.

Notes - The new species resembles Labrocarpon canariense (D. Hawksw.) Etayo \& PérezOrtega (basionym: Melaspilea canariensis D. Hawksw.) also growing on saxicolous species of Pertusaria, which differs in its lirelliform, sometimes branched, partly immersed to superficial apothecia with slit-like (never widely exposed) discs, excipular cells densely interspersed with dark brown granules, I+ blurry blue hymenium, smaller ascospores measuring $(13.8-) 15.4-19.8(-21.0) \times(6.0-) 6.8-8.6(-9.5) \mu \mathrm{m}$, $1 / \mathrm{b}=(1.9-) 2.1-2.5(-2.8)(\mathrm{n}=58$, in water, $\mathrm{K}, \mathrm{I}$ or $\mathrm{K} / \mathrm{I})$, and in the absence of gall-formation (examined topotype of Labrocarpon canariense). It is noteworthy, that in the examined specimens of Melaspilea galligena and Labrocarpon canariense we have not found distinct periphysoids developing from the inner part of exciple, which discriminate Labrocarpon Etayo \& Pérez-Ortega from Melaspilea Nyl. (Pérez-Ortega \& Etayo, 2010). However, in both compared specimens inward curved marginal parts of exciple contained poorly developed paraphyses, which might resemble periphysoids. In the examined specimen of Labrocarpon canariense we observed sometimes branched apothecia, exciple 20-50 $\mu \mathrm{m}$ thick, without basal stalk-like exten- 

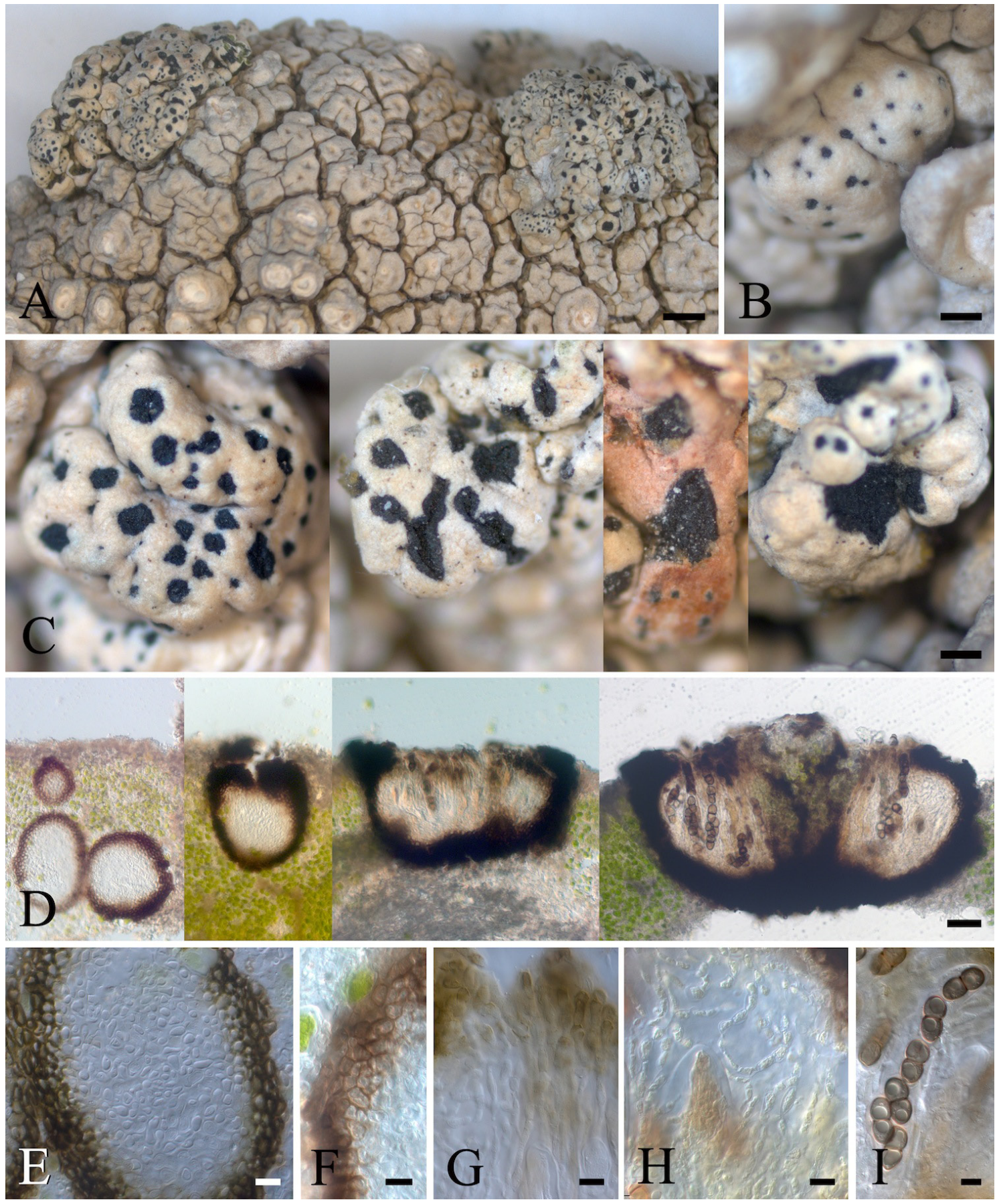

Fig. 3. Melaspilea galligena (holotype). A - gall-formation induced by the fungus; B, C - habitus of ascomata with different degree of hymenium exposition; D - cross sections of ascomata at different stages of maturation (in water); E - immature hamathecium resembling interascal pseudoparenchyma (in $\mathrm{K}$ ); $\mathrm{F}$ - exciple in cross section (in water); $\mathrm{G}$ - epithecium (in $\mathrm{K}$ ); $\mathrm{H}$ - mature hamathecium (in I), I- ascospores (in K). Bars: A $=1 \mathrm{~mm} ; \mathrm{B}, \mathrm{C}=200 \mu \mathrm{m} ; \mathrm{D}=50 \mu \mathrm{m} ; \mathrm{E}-\mathrm{I}=10 \mu \mathrm{m}$. 
sion, and a vague I+ blue staining of the hymenium, not mentioned in the species protologue (Hawksworth, 1982). We also confirm K/I+ blue reaction of its hymenium noted by Calatayud et al. (1995). Placement of the new species in $M e-$ laspilea seems to be most appropriate, despite the fact that species of this genus often have I+ blue hymenium, and are mostly lichenized, though often with evanescent or scarcely apparent thallus (Sanderson et al., 2009). Compared to the other Melaspilea species, M. galligena seems to be most similar to lichenicolous $M$. leciographioides Vouaux growing on Bagliettoa and Verrucaria, which can be distinguished by its superficial apothecia, I+ blue hymenium and smaller (to $3.5 \mu \mathrm{m}$ wide) apices of paraphyses (Roux et al., 2003; Sanderson et al., 2009). Treated material also strongly resembles species of lichenicolous genus Buelliella Fink, one of which, B. minimula (Tuck.) Hafellner, grows on Pertusaria. However, mature ascomata in this genus are sessile, and B. minimula is additionally distinguished by its smaller ascospores, 16-22 × 6-12 $\mu \mathrm{m}$, with perispore (Hafellner, 2004; Ihlen \& Wedin, 2008).

Specimen of Labrocarpon canariense examined for comparison - Africa, Canary Islands, Tenerife, S of Garachico, W of San Juan del reparo, $28^{\circ} 21^{\prime} \mathrm{N}, 16^{\circ} 45^{\prime} \mathrm{W}$, alt. ca. $565 \mathrm{~m}$, lava flow, on thallus of Pertusaria sp. growing on volcanic rock, 23.07.2007, P. Diederich (the specimen was collected in a site very close to the type locality and distributed by J. Hafellner as Lichenicolous Biota No. 25).

Merismatium heterophractum (Nyl.) Vouaux Yamal-Nenets Autonomous Area, SW coast of Baidaratskaya Bay, E of Ngoyuyakha River mouth, $68^{\circ} 51^{\prime} \mathrm{N}, 66^{\circ} 56^{\prime} \mathrm{E}$, on apothecia of Rinodina sp. growing on drift-wood, 27.07.2007 (LE 260708).

Note - Known from many regions of Russia, including Yamal-Nenets Autonomous Area (Zhurbenko, 2002b, 2007).

Neolamya Peltigerae (Mont.) Theiss. \& Syd. Krasnoyarsk Territory, Evenkiya District, lower Podkamennaya Tunguska River, Central Siberian Biosphere Reserve, lower Birobchana River, Kruten'kii Creek, 62²6'37.3"N, 91³6'32.6"E, on thallus of Peltigera didactyla, 19.08.2008 (LE 260890).

Note - The species was formerly known in Krasnoyarsk Territory (Central Siberia) only from Putorana Plateau (Zhurbenko \& Hafellner, 1999).
Phacopsis Cephalodioides (Nyl.) Triebel \& Rambold - Murmansk Region, Lapponia Imandrae,

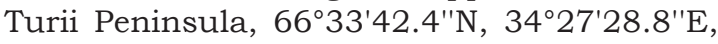
Picea obovata forest, on thallus of Hypogymnia physodes, 19.08.2009 (LE 260639); Kandalaksha Nature Reserve, Cape Turii, 66 $322^{\prime} 24.7^{\prime \prime} \mathrm{N}$, $34^{\circ} 30^{\prime} 04.0^{\prime \prime}$, Picea obovata forest, on thallus of Hypogymnia physodes, 19.08.2009 (LE 260619). - Perm Territory, Krasnovishersk District, Northern Ural, Visherskii Nature Reserve, near Lyp'ya village, $61^{\circ} 10^{\prime} 30^{\prime \prime} \mathrm{N}, 58^{\circ} 45^{\prime} 50^{\prime \prime} \mathrm{E}$, Betula forest, on thallus of Hypogymnia physodes, 13.07.2006 (LE 260669).

Note - New to Murmansk Region.

Phacopsis hUUSKoneni Räsänen - Krasnoyarsk Territory, Evenkiya District, lower Podkamennaya Tunguska River, Central Siberian Biosphere Reserve, near junction of Stolbovaya River and Berezovyi Creek, 62 16'43.4'N, 91'26'12.4"E, Picea obovata-Betula forest, on thallus of Bryoria fuscescens, 16.08.2008 (LE 260679).

Note - The species was formerly known in Krasnoyarsk Territory/ Central Siberia only from Stolby Reserve in the vicinities of Krasnoyarsk (Zhurbenko, 2012).

Phaeosporobulus alpinus R. Sant., Alstrup \& D. Hawksw. - Yamal-Nenets Autonomous Area, SW coast of Baidaratskaya Bay, E of Ngoyuyakha River mouth, 68 $51^{\prime} 01.1^{\prime \prime} \mathrm{N}, 66^{\circ} 53^{\prime} 03.0^{\prime \prime} \mathrm{E}$, tundra, on thallus of Ochrolechia sp. growing on mosses, 30.07.2007 (LE 260698b).

Note - Known from many regions of Russia, including Yamal-Nenets Autonomous Area (Zhurbenko, 2002b, 2007).

Phatosporobulus usneae D. Hawksw. \& Hafellner - Central Federal District, Vladimir Region, GusKhrustalny District, Meshchera National Park, NW of Kurlovskii, $55^{\circ} 28^{\prime} 08.2^{\prime \prime} \mathrm{N}, 40^{\circ} 34^{\prime} 40.3^{\prime \prime} \mathrm{E}$, Pinus sylvestris forest, on thallus of Usnea hirta, 7.10.2012 (LE 260640). - Krasnoyarsk Territory, Evenkiya District, lower Podkamennaya Tunguska River, Central Siberian Biosphere Reserve, lower Tanimakit River, 62 $2^{\circ} 30^{\prime} 00.4^{\prime \prime} \mathrm{N}$, $91^{\circ} 29^{\prime} 50.8^{\prime \prime} \mathrm{E}$, on lobes of Evernia mesomorpha growing on Picea, 18.08.2008 (LE 260789b). - Primorye Territory, Olga District, near Olga, $43^{\circ} 44^{\prime} 44.5^{\prime \prime} \mathrm{N}, 135^{\circ} 16^{\prime} 28.1^{\prime \prime} \mathrm{E}$, on thallus of $R a^{-}$ malina sp. growing on Quercus mongolica bark, 21.09.2007 (LE 260849). 
Note - New to Central Federal District and Primorye Territory.

Plectocarpon lichenum (Sommerf.) D. Hawksw. Perm Territory, Krasnovishersk District, Northern Ural, Visherskii Nature Reserve, Chuval'skii Kamen' Range, near Kuryksarka River mouth, $60^{\circ} 58^{\prime} \mathrm{N}, 58^{\circ} 52^{\prime} \mathrm{E}$, Picea forest, on thallus of Lobaria pulmonaria, 25.07.2006 (LE 260809). Note - New to Perm Territory.

Pseudopyrenidium TARTARICOla (Lindsay) Nav.Ros., Zhurb. et Cl. Roux - Yamal-Nenets Autonomous Area, SW coast of Baidaratskaya Bay, $\mathrm{E}$ of Ngoyuyakha River mouth, 68 $50^{\circ} 28.4^{\prime \prime} \mathrm{N}$, $66^{\circ} 55^{\prime} 59.3^{\prime \prime} \mathrm{E}$, tundra, on thallus of Ochrolechia inaequatula, 27.07.2007 (LE 260718).

Note - Known from many regions of Russia, including Yamal-Nenets Autonomous Area (Navarro-Rosinés et al., 2010).

Rhagadostoma lichenicola (De Not.) Keissl. Murmansk Region, Lapponia Imandrae, Khibiny Mountains, $2.5 \mathrm{~km}$ SE of Namuaiv Mountain, $67^{\circ} 50^{\prime} \mathrm{N}, 34^{\circ} 09^{\prime} \mathrm{E}$, alt. $400-450 \mathrm{~m}$, wet mountain tundra, on thallus of Solorina crocea, 08.08.1998 (LE 260759).

Note - Known from many regions of Russia, including Murmansk Region (Zhurbenko, 2001, 2007).

Sphaerellothecium minutum Hafellner - Perm Territory, Krasnovishersk District, Northern Ural, Visherskii Nature Reserve, $3 \mathrm{~km} \mathrm{NE}$ of Isherim Mountain, $61^{\circ} 09^{\prime} \mathrm{N}, 59^{\circ} 10^{\prime} \mathrm{E}$, alt. $900 \mathrm{~m}$, mountain tundra, on thallus of Sphaerophorus globosus, 20.07.2006 (LE 260709).

Note - New to Perm Territory.

STigmidium sp. - Krasnoyarsk Territory, Turukhansk District, near Podkamennaya Tunguska River mouth, Central Siberian Biosphere Reserve, right bank of Enisei River in front of $\mathrm{N}$ extremity of Komsinskii Island, $61^{\circ} 53^{\prime} \mathrm{N}$, $89^{\circ} 20^{\prime} \mathrm{E}$, on hymenium of apothecia and rarely thallus of Mycobilimbia tetramera growing on dead mosses at Populus tremula base, 07.07.2009 (LE 260850).

Description - Ascomata 35-60 $\mu \mathrm{m}$ diam., semiimmersed to almost sessile, crowded, often contiguous. Asci (22-)26-34(-41) × 11-13(-15) $\mu \mathrm{m}$ ( $\mathrm{n}=29$, in water or $\mathrm{BCr}$ ). Ascospores hyaline, 1 -septate, not or rarely slightly constricted at the septum, usually pseudotetrablastic, halo not observed, smooth or possibly occasionally verruculose when old, (10.0-) 10.7-12.1(-12.7) × (3.0-)3.2-3.6(-3.8) $\mu \mathrm{m}, 1 / \mathrm{b}=(2.8-) 3.0-3.6(-4.0)$ ( $\mathrm{n}=23$, in water). Walls of asci and ascospores $\mathrm{BCr}-$, pycnidial gel here and there $\mathrm{BCr}+$ violet. Infected hymenium of the host is bleached or darkened.

Notes - Stigmidium mycobilimbiae Cl. Roux, Triebel \& Etayo, the only species of the genus formerly reported on Mycobilimbia, differs from the examined specimen in its larger ascomata $(60-90 \times 55-75 \mu \mathrm{m}), \mathrm{BCr}+$ violet reaction of the ascospore wall and larger ascospores $[(10.5-) 11.5-16.0(-16.5) \times(2.5-) 3.0-4.0(-4.5)$ $\mu \mathrm{m}]$, which are 1(-3)-septate (Roux \& Triebel, 1994). This species grows parasymbiotically on the thalli of host lichens.

Stigmidium cf. squamariae (de Lesd.) Cl. Roux \& Triebel - Central Federal District, Smolensk Region, Demidov District, Smolensk Lakeland National Park, near Evseevka, 55 $43^{\prime} \mathrm{N}, 31^{\circ} 52^{\prime} \mathrm{E}$, on hymenium of apothecia of Lecanora polytropa growing on open boulder, 1.06.2005 (LE 260659).

Notes - Ascomata 25-35 $\mu \mathrm{m}$ diam., mostly immersed and erumpent only in ostiolar area, crowded. Ascospores hyaline, (7.0-)8.0-9.4(-9.7) $\times(3.2-) 3.5-4.1(-4.4) \mu \mathrm{m}, 1 / \mathrm{b}=(2.0-) 2.1-2.5(-2.8)$ ( $\mathrm{n}=34$, in $\mathrm{BCr}$ ), 1-septate, wall smooth, distinct halo not observed, not pseudotetrablastic. Infected host hymenium becomes dark. According to Roux \& Triebel $(1994,2005)$ S. squamariae has larger ascomata $(60-75 \times 40-55 \mu \mathrm{m})$ and larger ascospores [(8.5-)9.5-12.5(-14.0) $\times$ (4.0-)5.0-5.5(-6.0) $\mu \mathrm{m}]$ with quite visible halo; it has been formerly reported in Central Federal District only from Tver Region (Notov et al., 2011).

Taeniolella beschiana Diederich - Krasnoyarsk Territory, Evenkiya District, lower Podkamennaya Tunguska River, Central Siberian Biosphere Reserve, lower Usas River, 62 ${ }^{\circ} 12^{\prime} 14.6^{\prime \prime} \mathrm{N}$, $91^{\circ} 09^{\prime} 53.7^{\prime \prime} \mathrm{E}$, on basal squamules of Cladonia sp. growing on soil, 13.07.2009 (LE 260830).

Note - The species was formerly known in Krasnoyarsk Territory only from Taimyr Peninsula (Zhurbenko, 1998; Zhurbenko \& Alstrup, 2004).

ToniniA sp. - Central Federal District, Ryasan Region, Spassk District, Okskii Biosphere Reserve, Brykin Bor, 54 $42^{\prime} 40^{\prime \prime} \mathrm{N}, 40^{\circ} 51^{\prime} 10^{\prime \prime} \mathrm{E}$, broadleaf 
forest, on thallus of Parmelina tiliacea growing on Tilia cordata bark, 4.05.2007 (LE 260719). Description (Fig. 4) - Lichenization not observed. Ascomata apothecia, black, glossy, epruinose, rough, (100-)150-350(-500) $\mu \mathrm{m}$ diam., sessile, at first subglobose to turbinate, then cupshaped or discoid, constricted at the base, disc concave then plane to slightly convex, with a slightly elevated, finally sometimes disappearing margin, dispersed to adjacent. Proper exciple annular, prosoplectenchymatic, dark to medium purplish/vinaceous brown, paler in the inner parts, lacking crystals, $25-60 \mu \mathrm{m}$ thick, in cross section composed of radially arranged cells with ellipsoid to narrowly cylindrical lumina and walls $1.5-3 \mu \mathrm{m}$ thick, $\mathrm{K}-, \mathrm{N}+$ reddish purple or violet (coloration fading). Hypothecium hyaline, lacking crystals, up to $100 \mu \mathrm{m}$ tall, merging with exciple below. Epithecium medium to dark bluish green, lacking crystals, 5-10 $\mu \mathrm{m}$ tall,
$\mathrm{K}-, \mathrm{N}+$ lilac to violet (coloration disappearing). Hymenium hyaline, 40-55 $\mu \mathrm{m}$ tall, I+ red, K/ I+ blue with vertical red streaks. Paraphyses straight, septate, unbranched, ca. $1.5 \mu \mathrm{m}$ diam., with swollen, diffusely unevenly bluish green apices (pigments encrust cell walls, which is better seen in K), 2-4(-6) $\mu \mathrm{m}$ diam., not conglutinated. Asci subcylindrical to broadly clavate, wall $\mathrm{I}$ and $\mathrm{K} / \mathrm{I}-$, surrounded by a I+ red, K/I+ blue or occasionally red gelatinous sheath $1-2$ $\mu \mathrm{m}$ thick, tholus usually well-developed (clearly seen in somewhat immature asci), up to $12 \mu \mathrm{m}$ tall, I and K/I+ blue, containing well-developed conical ocular chamber, (39-)43-51(-57) $\times$ (9-) 10-12(-13) $\mu \mathrm{m}(\mathrm{n}=34$, in water, I or $\mathrm{K} / \mathrm{I})$, 8-spored. Ascospores hyaline, bacilliform, rarely spathulate or naviculate, straight or slightly curved, isodiametric or often with somewhat thicker upper part, ends more or less rounded, $(15.0-) 22.0-38.2(-52.0) \times(1.6-) 1.9-2.7(-3.9) \mu \mathrm{m}$,
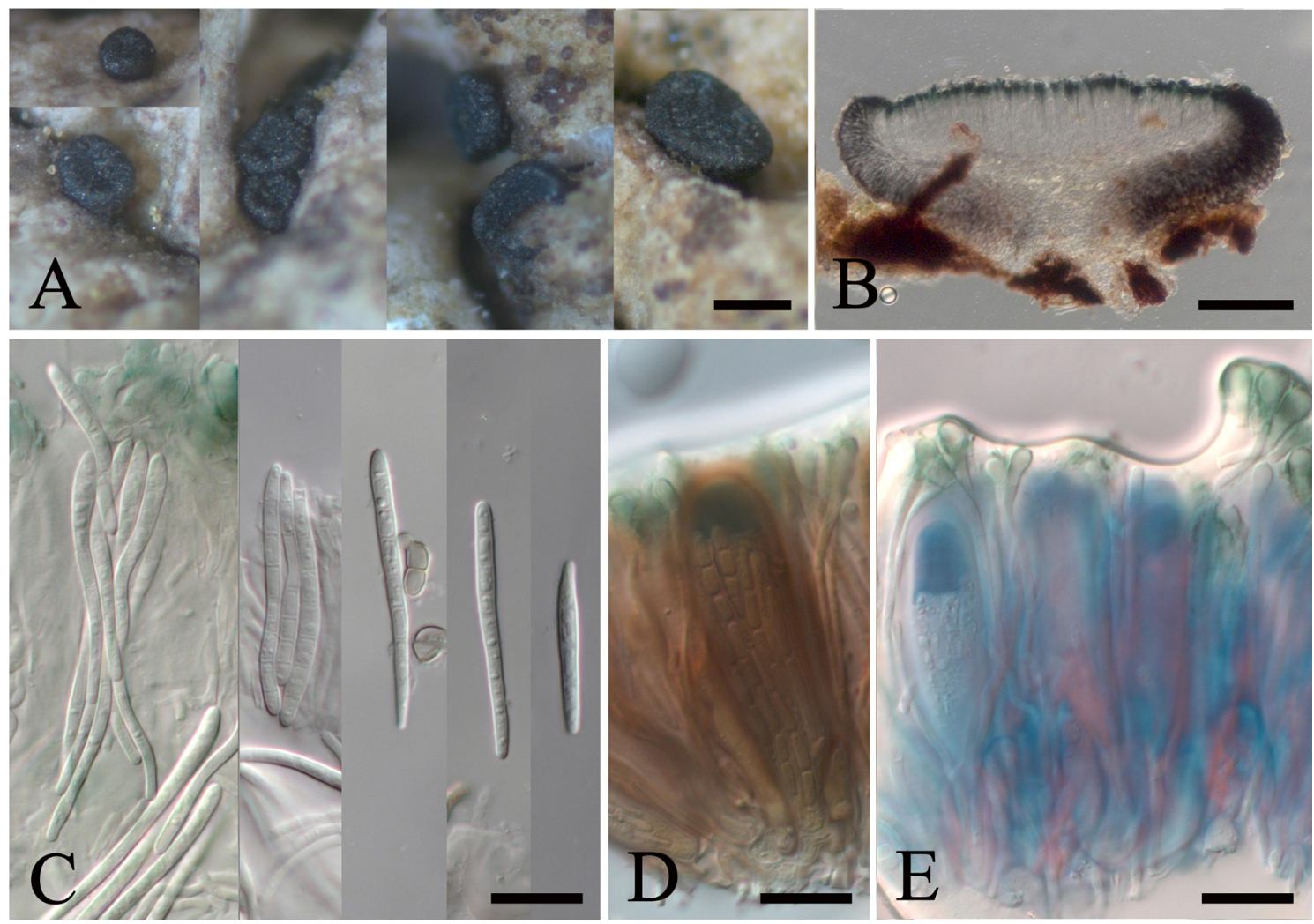

Fig. 4. Toninia sp. growing on Parmelina tiliacea (LE 260719). A - habitus of apothecia; B - apothecium in cross section (in water); $\mathrm{C}$ - ascospores (in $\mathrm{K}$ ); $\mathrm{D}$ - hymenium with asci (in I); $\mathrm{E}$ - hymenium with asci (in K/I); Bars: $\mathrm{A}=200 \mu \mathrm{m} ; \mathrm{B}=100 \mu \mathrm{m} ; \mathrm{C}-\mathrm{E}=10 \mu \mathrm{m}$. 
$1 / \mathrm{b}=(4.2-) 9.3-17.3(-23.5)(\mathrm{n}=87$, in water, $\mathrm{K}, \mathrm{I}$ or K/I), (1-)3-7(-9)-transseptate, not constricted at the septa, guttulate (best seen in K), wall thin, smooth, non-halonate, usually arranged in an ascus in one bunch. Conidiomata not observed. Developed on the upper side of Parmelina tiliacea lobes, mainly by their margins, sometimes on more or less moribund host parts. Pathogenicity not observed.

Notes - Examined material possibly represents a new lichenicolous species of Toninia, but more material is needed to verify this assumption. The other so far known lichenicolous not or weakly lichenized Toninia species, viz. T. collematicola Timdal (growing on Collema), $T$. episema (Nyl.) Timdal (on Circinaria), T. leptogii Timdal (on Collema and Leptogium), T. plumbina (Anzi) Hafellner \& Timdal (mainly on Degelia), T. subdispersa (Nyl. ex Hasse) K. Knudsen (on Lecania), T. subfuscae (Arnold) Timdal (on Caloplaca, Lecanora, Lecidella, Pertusaria and Verrucaria), T. subtalparum van den Boom (on Lecania), T. ualae Etayo (on Nephroma and Pseudocyphellaria), and T. verrucariae (Metzler ex Nyl.) Timdal (mainly on Bagliettoa and Verrucaria), differ from the studied specimen in their host selection and some taxonomically essential characters (Clauzade et al., 1989; Timdal, 1991; Rambold \& Triebel, 1992; Boqueras, 2000; van den Boom, 2004; Spribille et al., 2006; Knudsen \& Lendemer, 2007; Etayo \& Sancho, 2008; Brackel, 2009). Among these Toninia ualae, a recently described from Chile weakly lichenized species with granulose or sometimes indistinct thallus, seems to be most similar to the treated species. However, it clearly differs from the latter in having sometimes white pruinose apothecia, hyaline to gray, $\mathrm{K}+$ proper exciple, dark grey, $\mathrm{K}+$ epithecium with crystals, sometimes branched paraphyses without swollen apical cells, and shorter ascospores [(18-)21-30(-37) × 2-2.5(-3) $\mu \mathrm{m}]$, which are slightly constricted at the septa (Etayo \& Sancho 2008: Fig. 119). Toninia episema, T. leptogii, T. subdispersa, T. subtalparum, and $T$. verrucariae are easily distinguished from the present species by their simple or 1-septate ascospores. Toninia collematicola has pruinose apothecia, dark grey, $\mathrm{K}+$ violet proper exciple, grey, $\mathrm{K}+$ violet epithecium, and $3(-5)$-septate

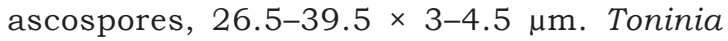
plumbina differs in having dark brown hypothecium and narrowly fusiform to bacilliform, (1-)3(-5)-septate ascospores, 18.5-29 × 3-4.5 $\mu \mathrm{m}$. Toninia subfuscae has reddish brown hypothecium and 1-3-septate, ellipsoid to shortly bacilliform ascospores, 9.5-16 × 4-5.5 $\mu \mathrm{m}$. Examined material also strongly recalls some Bacidia species, particularly $B$. bagliettoana and $B$. subincompta, which mainly differ in being lichenized and in having pigmented hypothecium (Ekman, 2004).

Tremella Cetraricola Diederich \& Coppins Murmansk Region, Karelia Keretina, Kandalaksha Nature Reserve, N coast of Velikii Island, $66^{\circ} 35^{\prime} 27.4^{\prime \prime} \mathrm{N}, 33^{\circ} 21^{\prime} 30.0^{\prime \prime} \mathrm{E}$, supralittoral, on thallus of Cetrariella delisei, 8.07.2008 (LE 260739); same reserve, Kovdskii Peninsula, N of

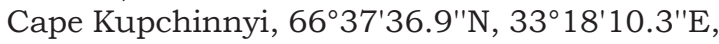
supralittoral, on thallus of Cetrariella delisei, 5.08.2009 (LE 260749). - Krasnoyarsk Territory, Evenkiya District, lower Podkamennaya Tunguska River, Central Siberian Biosphere Reserve, near Stolbovaya River mouth, 62 $07^{\prime} 25.0^{\prime \prime} \mathrm{N}$, 91'30'40.6"E, Picea obovata-Betula forest, on upper side of Tuckermannopsis ciliaris lobes, 14.08.2008 (LE 260859).

Note - New to Siberia.

TREmella EVERniae Diederich - Krasnoyarsk Territory, Evenkiya District, lower Podkamennaya Tunguska River, Central Siberian Biosphere Reserve, near junction of Stolbovaya River and Berezovyi Creek, 62 ${ }^{\circ} 16^{\prime} 43.4^{\prime \prime} \mathrm{N}, 91^{\circ} 26^{\prime} 12.4^{\prime \prime} \mathrm{E}$, Picea obovata-Betula forest, on lobes of Evernia mesomorpha growing on Picea, 16.08.2008 (LE 260699); same reserve, lower Tanimakit River, $62^{\circ} 30^{\prime} 00.4^{\prime \prime} \mathrm{N}, 91^{\circ} 29^{\prime} 50.8^{\prime \prime} \mathrm{E}$, on lobes of $E$. mesomorpha growing on Picea, 18.08.2008 (LE 260789a).

Note - Formerly known in Russia only from Stolby Nature Reserve near Krasnoyarsk (Zhurbenko, 2012).

Tremella hypogymniae Diederich \& M.S. Christ. - Murmansk Region, Karelia Keretina, Kandalaksha Nature Reserve, Velikii Island, near

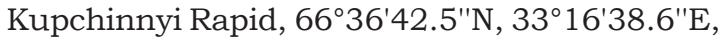
Pinus sylvestris-Betula forest, on thallus of $\mathrm{Hy}$ pogymnia physodes, 8.08.2009 (LE 260689). Krasnoyarsk Territory, Evenkiya District, lower Podkamennaya Tunguska River, Central Siberian Biosphere Reserve, lower Tanimakit River, $62^{\circ} 29^{\prime} 30.1^{\prime \prime} \mathrm{N}, 91^{\circ} 30^{\prime} 10.9^{\prime \prime} \mathrm{E}$, Betula forest, on thallus of Hypogymnia physodes, 18.08.2008 (LE 260810).

Note - New to Murmansk Region. 


\section{ACKNOWLEDGEMENTS}

Wolfgang von Brackel, Paul Diederich, Stefan Ekman, Javier Etayo and Einar Timdal are thanked for valuable comments on Arthonia cf. lepidophila, Melaspilea galligena and/or Toninia sp. on Parmelina tiliacea. The second author is indebted to Vadim Bakalin, Zoya Drozdova, Tatyana Khasminskaya, Nadezhda Konstantinova, Alexandr Koryakin, Mikhail Kozhin, Victor Krainov, Antonina Lobanova, Dmitriy Ochagov, Andrey Sapogov, Svetlana Shcherbina, Yelena Shutova and Ludmila Volosnova for assistance in his field work.

\section{REFERENCES}

Anzi, M. 1868. Analecta lichenum rariorum vel novorum Italiae Superioris. Atti della Societa Italiana di Scienze Naturali 11: 156-181.

Boqueras, M. 2000. Liquens Epifits i Fongs Liquenicoles del Sud de Catalunya: Flora $i$ Comunitats [The Epiphytic Lichens and Lichenicolous Fungi of South Catalonia: Flora and Communities]. Institut d'Estudis Catalans, Barcelona. 556 pp.

Brackel, W. v. 2009. Weitere Funde von flechtenbewohnenden Pilzen in Bayern - Beitrag zu einer Checkliste IV. Berichte der Bayerischen Botanischen Gesellschaft 79: 5-55.

Calatayud, V., Atienza, V. \& Barreno, E. 1995. Lichenicolous fungi from the Iberian Peninsula and the Canary Islands. Mycotaxon 55: 363-382.

Clauzade, G., Diederich, P. \& Roux, C. 1989. Nelikenigintaj fungoj likenlogaj. Ilustrita determinlibro. Bulletin de la Société Linnéenne de Provence, Numero Special 1: 1-142.

Ekman, S. 2004. Bacidia. In: Nash III, T. H., Ryan, B. D., Diederich, P., Gries, C. \& Bungartz, F. (eds). Lichen Flora of the Greater Sonoran Desert Region, Vol. 2. Lichens Unlimited, Arizona State University, Tempe, Arizona, pp. 18-28.

Etayo, J. \& Sancho, L. G. 2008. Hongos liquenícolas del Sur de Sudamérica, especialmente de Isla Navarino (Chile). Bibliotheca Lichenologica 98: 1-302.

Fryday, A. M. \& Coppins, B. J. 2012. New taxa, reports, and names of lichenized and lichenicolous fungi, mainly from the Scottish Highlands. The Lichenologist 44(6): 723-737. http:/ / dx.doi. org/10.1017/S0024282912000369

Hafellner, J. 1994. Beiträge zu einem Prodromus der lichenicolen Pilze Österreichs und angrenzender Gebiete. I. Einige neue oder seltene Arten. Herzogia 10: 1-28.

Hafellner, J. 2004. Buelliella. In: Nash III, T. H., Ryan, B. D., Diederich, P., Gries, C. \& Bungartz, F. (eds). Lichen Flora of the Greater Sonoran Desert Region, Vol. 2. Lichens Unlimited, Arizona State University, Tempe, Arizona, pp. 633-635.
Hawksworth, D. L. 1982. Melaspilea canariensis sp. nov. and other lichenicolous fungi from Tenerife. The Lichenologist 14: 83-86. http://dx.doi. org/10.1017/S0024282982000127

Ihlen, P. G. \& Wedin, M. 2008. An annotated key to the lichenicolous Ascomycota (including mitosporic morphs) of Sweden. Nova Hedwigia 86(3-4): 275-365. http://dx.doi.org/10.1127/00295035/2008/0086-0275

Keissler, K. von. 1930. Die Flechtenparasiten. In: Dr. L. Rabenhorst's Kryptogamen-Flora 8: 1-712. Akademische Verlagsgesellschaft, Leipzig.

Knudsen, K. \& Lendemer, J. C. 2007. Studies in lichens and lichenicolous fungi: notes on some North American taxa. Mycotaxon 101: 81-87.

Navarro-Rosinés, P., Zhurbenko, M. P. \& Roux, C. 2010. Pseudopyrenidium nova genro por inkludi Weddellomyces tartaricola (nelikeniôinta fungo likenloĝa, Ascomycota). Bulletin de la Société Linnéenne de Provence 61: 129-140.

Notov, A. A., Himelbrant, D. E. \& Urbanavichus, G. P. 2011. Annotated list of lichen flora of Tver Region (in Russian). Tver: Tver state University. 124 pp.

Pérez-Ortega, S. \& Etayo, J. 2010. Labrocarpon gen. nov. for Melaspilea canariensis, with the description of Buelliella protoparmeliopsis sp. nov. from South America. The Lichenologist 41(3): 271-276. http://dx.doi.org/10.1017/S0024282909990624

Rambold, G. \& Triebel, D. 1992. The Inter-lecanoralean Associations. Bibliotheca Lichenologica 48: 1-201.

Roux, C., Bricaud, O., Ménard, T., Gueidan, C., Coste, C. \& Navarro-Rosinés, P. 2003. Champignons lichénisés et lichénicoles de la France méridionale (Corse comprise): espèces nouvelles et intéressantes (9). Bulletin de la Société Linnéenne de Provence 54: 125-141.

Roux, C. \& Triebel, D. 1994. Révision des espèces de Stigmidium et de Sphaerellothecium (champignons lichénicoles non lichénisés, Ascomycetes) correspondant à Pharcidia epicymatia sensu Keissler ou à Stigmidium schaereri auct. Bulletin de la Société Linnéenne de Provence 45: 451-542.

Roux, C. \& Triebel, D. 2005. L'hamathécium de Stigmidium squamariae, ascomycète lichénicole non lichénisé - conséquences systématiques. Mycotaxon 91: 133-136.

Sanderson, N. A., Hawksworth, D. L. \& Aptroot, A. 2009. Melaspilea Nyl. (1857). In: Smith, C. W. et al. (eds). The Lichens of Great Britain and Ireland. The British Lichen Society, London. pp. 576-579.

Spribille, T., Schultz, M., Breuss, O. \& Bergmeier, E. 2006. Notes on the lichens and lichenicolous fungi of western Crete (Greece). Herzogia 19: 125-148.

Timdal, E. 1991. A monograph of the genus Toninia (Lecideaceae, Ascomycetes). Opera Botanica 110: $1-137$.

Urbanavichus, G., Ahti, T. \& Urbanavichene, I. 2008. Catalogue of lichens and allied fungi of Murmansk Region, Russia. Norrlinia 17: 1-80. 
van den Boom, P. P. G. 2004. Toninia. In: Nash III, T. H., Ryan, B. D., Diederich, P., Gries, C. \& Bungartz, F. (eds). Lichen Flora of the Greater Sonoran Desert Region, Vol. 2. Lichens Unlimited, Arizona State University, Tempe, Arizona, pp. 708-709.

Zhurbenko, M. P. 1998. Lichens and lichenicolous fungi from the north of Pyasino lake, Taimyr peninsula, Siberia. Folia Cryptogamica Estonica 32: 153-159.

Zhurbenko, M. P. 2001. Lichenicolous fungi from Murmansk region of Russia. Mikologiya i Fitopatologiya 35(1): 34-40.

Zhurbenko, M. P. 2002a. Arthonia triebeliae (Arthoniales), a new lichenicolous fungus from the Arctic. Mycological Progress 1(2): 137-141. http:/ /dx.doi. org/10.1007/s11557-006-0012-0

Zhurbenko, M.P. 2002b. Lichenicolous fungi from the Polar Ural. Mikologiya i Fitopatologiya 36(6): 9-14.
Zhurbenko, M. P. 2007. The lichenicolous fungi of Russia: geographical overview and a first checklist. Mycologia Balcanica 4: 105-124.

Zhurbenko, M. P. 2009. Lichenicolous fungi and some lichens from the Holarctic. Opuscula Philolichenum 6: 87-120.

Zhurbenko, M. P. 2012. New records of lichenicolous fungi from "Stolby" Reserve (Krasnoyarsk Territory). Novitates Systematicae Plantarum non Vascularium (St.-Petersburg) 46: 92-95. (In Russian, English summary).

Zhurbenko, M. P. \& Alstrup, V. 2004. Lichenicolous fungi on Cladonia mainly from the Arctic. Symbolae Botanicae Upsalienses, Acta Universitatis Upsaliensis 34(1): 477-499.

Zhurbenko, M. P. \& Hafellner, J. 1999. Lichenicolous fungi from the Putorana Plateau, Siberian Subarctic. Folia Cryptogamica Estonica 34: 71-79. 
100 Folia Cryptog. Estonica 